\title{
Social Transformation including Class Conflict, Historical Restrictions and Free Will
}

\section{Freddy Cante}

Facultad de Estudios Internacionales, Politicos y Urbanos, Universidad del Rosario, Bogotá, Colombia

Email: fredy.cante@urosario.edu.co

How to cite this paper: Cante, F. (2020). Social Transformation including Class Conflict, Historical Restrictions and Free Will. Open Journal of Social Sciences, 8, 267-281. https://doi.org/10.4236/jss.2020.86024

Received: March 27, 2020

Accepted: June 13, 2020

Published: June 16, 2020

Copyright $\odot 2020$ by author(s) and Scientific Research Publishing Inc. This work is licensed under the Creative Commons Attribution International License (CC BY 4.0).

http://creativecommons.org/licenses/by/4.0/

\begin{abstract}
This article of critical review proposes an explanation of social choice which is understood as a conflictive process of social transformation because society is divided into rival or antagonistic social classes. There are some historical restrictions to social change but there are possibilities of reformist or revolutionary transformation that arise from free will. The changes and social choices are transitory and uncertain due to persistent conflict and free will. In the conclusions, some research perspectives are offered and a brief remark on the acts of free will that are produced by the environment and by nature itself, generates colossal social transformations (as, for example, those derived from the COVID-19 pandemic).
\end{abstract}

\section{Keywords}

Social Choice, Uncertainty, Free Will, Strategic Secret

\section{Introduction}

Society is divided into rival or antagonistic social classes and consequently social choice is an extremely conflictive process that can culminate in reformist or revolutionary social transformations. It can also have unexpected and surprising results even for those who have promoted social changes.

In the last half century, throughout the world, extreme conflicts have occurred between rival social classes. Some rebel social sectors, in May 1968, made some progress in civil liberties. However, from the beginning of the 1970s to the end of the second decade of the XXI century, the conservative and privileged classes imposed neoliberalism and promoted globalization. The attempts at social reform promoted by social democrats and the revolutionary changes announced by 21 st century socialism were notably frustrated by the historical restrictions of capitalism. The protests of dissatisfied social classes and youth against neolibe- 
ralism were frequent and global last year. The spring of 2020 reveals the withering and paralysis of capitalism and globalization. A virus shows us that societies had promoted innovations for war and business but not for the care and health of people. But more uncertain than the advance of the pandemic is the future of a world with millions of people locked up and a possible resurgence of authoritarianism and vigilance. This, like all conflicts, is uncertain and continuous.

In general terms, the author of this article assumes that there are two rival or antagonistic social classes, namely: the privileged classes that defend an established social order versus the impaired classes that are dissatisfied with the given and imperfect order and that, consequently, seek a reformist or revolutionary social transformation.

According to Sen (2009: p. 91), the theory of social choice emerged during the turbulent times of the French revolution. However, the pioneers and followers of conventional social choice theory ignore class conflict. They assume that the process of collective choice consists of the aggregation of the individual preferences of the members of a society. That conventional perspective was revived by the influential Arrow economist in the mid-20th century.

The approach adopted here consists of an interpretation of social choice theory through the lenses of authors such as Marx, who rightly showed that societies are divided into rival or antagonistic classes.

Marx's contributions are related to the theory of social choice. Sen (2009: p. 7) notes that Marx, as an enlightenment theorist, discussed social justice by making some comparisons of social achievement in different types of society. The comparability of societies and individuals is a fundamental element in the theories of justice and social choice, and allows us to know who is privileged and who is harmed by a social order.

This article of critical review offers a novel theorization of social choice which is understood as a process of social transformation subject to class struggle. Social change is subject to strong historical constraints which materialize in the economic, social, political, and mental structures of a given social state. Such restrictions can be partially or totally overcome if the individuals and social classes that promote transformations act with originality, creativity, imagination and put the skin in the game (they have very strong preferences).

Thanks to the reading of relevant theories and some available empirical evidence, it is possible to show two realities, namely: first, genuine social transformation may be possible when at least some individuals have free will and, consequently, their acts and choices are in the realm of uncertainty (their choices and actions cannot be foreseen or, even less, controlled by someone else); Second, the reforms or revolutions resulting from this process are not usually agreed upon and, consequently, the social sectors that promote social changes try to impose their will over the rest of society.

The social choice is inconclusive, fragmentary, incessant, conflictive, contradictory and always transient and unstable. 
In the second section is raised a novel theorization of the social choice; subsequently, in third is explained the process of class conflict and social transformation. In the fourth section is showed some empirical evidence that has allowed us to discuss the hypothesis. Finally, the conclusions offer some research perspectives and a brief remark on the acts of free will produced by the environment and by nature itself generates colossal social transformations - all this about the COVID-19.

\section{Social Choice: Historical Constraints, Conflict and Free Will}

Social choice is a protracted, unfinished, agonistic and imperfect process of election and transformation of social order. In every process of social choice exist a permanent dissent and conflict of antagonistic or rival social classes. The most notable feature of social choice is the agonistic, contentious and confrontational and episodic character of collective choices. There is a succession of collective choices that are imposed on the rest of society by the dominant social class in every particular fragment of history.

Some of the fundamental elements of a more realistic view of social choice are: historical restrictions, class conflict and free will.

\subsection{Social Order and Social States}

Erroneously Arrow followed the interpretation of Knight (1982) and argued that in modern liberal democracies social choice is a purely deliberate and rational choice (that is, a process without institutional and historical restrictions).

In a more realistic view of social choice historical restrictions partially delimit social choices and prevent divergent social election processes, even the most radical and revolutionary, from being completely original and novel. This article emphasizes that historical restrictions are equivalent to existent social states.

A social state is understood as an institutional structure that precedes and delimits the choice of individuals and collectivities.

The existing social order in any historical moment is equivalent to an imperfect and inconclusive social state. This incomplete order is mainly the result of a spontaneous and protracted collective action. According to Hayek (1960) and Popper (2001), this spontaneous collective action is evolutionary and allows us to solve problems through trial and error.

The social order is unstable because society is divided into rival or antagonistic social classes that fight each other. In every social order, there is a hard conflict between the old and the new, what is preserved and what is renewed. The social choice is then evolutionary and conflictive: individuals are born and are formed in an order that has been imposed, some social class want to preserve it and other social class seek to change it.

Arrow (1963) is correct in stating that, in every social state, there is an established use and allocation of economic resources, distribution of wealth and in- 
come, established social positions, rules of the game (formal and informal social norms) and, also pecuniary and symbolic retributions to the various heroes.

However, here it is added that: Every social state is institutionalized and partially shapes the preferences, values, passions, whims, tastes, and conditions of individuals. Social conventions (such as language and money), emotions and feelings and also various customs are, in large part, determined by existing social states.

In an institutionalized social state each individual occupies a position (economic, social and political) and lives in a specific situation of time and place that, to a large extent, has not been the result of his or her choice. Each individual belongs to a certain social class although she or he has the freedom to maintain or withdraw their loyalty to that social class.

Following the perspective of Portes (2006), the dominant social order (in any society and historical moment) is governed by some rules of the game and by some authorities. The existing rules of the game are informal norms (bequeathed and historically imposed by past generations, and obeyed by custom and diverse mental structures) and formal norms (imposed by States, laws and formal mandates). The authorities are individuals with hierarchical roles compatible with the macro-social relations (the political class) and micro-social interactions (the various chiefs and administrators who govern organizations such as churches, armies, schools, factories, unions, political parties, etc.).

When the social order works without frictions, tensions, and conflicts, individuals assume passively their roles as authorities and as subjects. They do not choose. They docilely comply with a libretto prefigured by formal and informal rules. There may be herds of wantons or automatons who follow the will of an institution or who are governed by some ecclesiastical, military or ideological authority.

When social class differences emerge and class conflicts and dissent arise then there is an environment for change. Social changes are possible if there is genuine individual and collective freedom to choose.

\subsection{Individual Free Will versus Imposed Social Order}

There are processes of reform and revolution against the prevailing social order. These kinds of collective actions are led or are initiated by some minorities of dissatisfied and creative individuals.

According to Frankfurt (1971) and Hirschman (1982), frequently the immense majorities of individuals are a kind of senseless beings (wanton). Additionally, as Skinner (1998) sharply raises it a majority of individuals are subjects with ridiculous private and often cosmetic liberties and they ignore or do not seek to participate in political decisions concerning society.

The processes of collective insubordination to seek social changes are initiated by minorities of individuals who reach to be persons, that is, who critically judge the institutional structures, the dominant social classes and the imposed authori- 
ties. According to Frankfurt (1971) these minorities of people can make second-order choices or volitions. They conceive values or meta-preferences that are different from the dominant ones, as has been raised, respectively, by Hirschman (1982) and Sen (1967).

Social transformation and the creation of new and original values are possible if there is free will.

According to authors such as Shackle (1966) and Kane (2011) free will is incompatible with determinism (effects that obey a cause, future predetermined by history and certainties about regularities and laws) and, therefore, is compatible with the indeterminate and the uncertain.

Taking as starting point certain relevant theoretical referents (Shackle, 1990; Frankfurt, 1971; Kane, 2011; Ekstrom, 2011; Taleb, 2008), the concept of free will suggested in this article has three basic characteristics, namely:

Self-determination (autonomy): an individual is autonomous when he has formed critical and proper thinking about the established social order and, consequently, seeks to rebel or get out of the norms and inherited questionable values. The individual becomes a person when he forms his volitions (second-order volitions about values or worldviews). The autonomous individual determines his course of action (acts motivated by his own will) and is not a piece of gear that obeys exogenous forces of history and society.

Creativity: an individual is creative when, originally, she or he generates new options or solutions (not previously existing or determined by the past) and then incorporates a novelty in her or his personal history and also in the collective one. Artistic, scientific and technological creations and the generation of innovative social models and new values and ideologies are part of this creativity. It also includes novel strategic actions such as strategic secrecy, surprise action and the alteration and subversion of established norms.

The intensity of preferences: so that autonomy and creativity do not remain in the terrain of subjective elaborations and are transformed into concrete actions, it is crucial that individuals have willpower and assume risks and responsibilities for their actions. Following the approach of Taleb (2018), the intensity of preferences transcends the bet of one's fortune and compromises the integrity of the being that puts his life at risk and puts the skin in the game.

Free will can be ascertained when the choices and actions of an individual (or of a group of individuals) cannot be foreseen and cannot be controlled by any authority, or hindered by the interference of someone else (Barrow, 1998).

Individual and collective choices that are the product of free will generate uncertainty.

According to Shackle (1991) the uncertainty is not subject to the calculation of probabilities. The probability can be calculated in a deterministic world that is subject to stable structures. In this world, which is considerably predictable, the chance is domesticated and the choices of individuals are determined by historical antecedents (and controlled and domesticated by authorities). In this deter- 
ministic environment, individual and collective choices are scripts dictated by institutions and authorities, and their behaviors are simple effects that obey some causes. In the calculation of probabilities, typical of rational choice, it is assumed that individuals can know a list of foreseeable future events and, also, the ways and procedures to access them. The probabilities can then be calculated because the social structures are stable because the only variable is the facets of a repetitive cycle. In a world of uncertainty (and free will) there is no list of possible futures since the genuine choice that is libertarian and uncertain occurs when individuals imagine, create and, then, incorporate novelty and surprise in the future. When individuals and collectivities create, with originality, new uncertain and indeterminate events (not completely subject to causes and institutional constraints) then they have free will.

As rightly argues (Shackle, 1990), we do not live in a world of total uncertainty because that would imply a permanent disorder and supreme instability. What exists is a world of limited uncertainty (and, therefore, of bounded free will) because the original creations of individuals are, partially, subject to historical conditions and some institutional restrictions. Not everything imaginable is possible in the historical conditions and institutional restrictions experienced by different individuals. Nevertheless, the creations and innovations of some individuals amount to transformations of the world that are not completely restricted, that go beyond what is socially permissible and then are not foreseeable or even less controllable.

\subsection{Irrelevant Options and Free Will}

According to Shackle (1990), the choice is impotent and, therefore, not free in a deterministic world where there are given alternatives. In that environment, voters are limited to ordering or prioritizing previously existing or established options (as in the rational choice).

Conventional theorists of Social Choice have assumed a rational choice without freedom. They have supposed that there is a set of options given to every individual. For them, the set of options remains unchanged because the incorporation of the so-called irrelevant options is not allowed. Nevertheless in the real world, irrelevant options emerge due to the variations inherent in the permanent becoming and social transformation.

The idea of libertarian election raised here is that free will constitutes an originative and creative action and, therefore, there is no freedom of choice in a world with given options and imposed procedures.

Free will is beyond the unrestricted domain and it is the most important attribute of libertarian individual and collective choices. This is the source of subversion and innovation that can result in important processes of social transformation. Free will, even if it is about some options, apparently irrelevant, is the foundation of new social states or of important transformations of a given social state. 
In a non-deterministic environment (of uncertainty), the future is radically unknown and there are not a handful of probable future events. Possibly each human being can have free will to influence at least one irrelevant option, which can vary their personal history and, perhaps, alter the course of future collective history.

In the approach proposed in this article, it is suggested that individuals, with their free will, can only influence the transformation of some details of existing social states and, also, some aspects of the existing natural world. These minute details are equivalent to the so-called irrelevant options (which are not included in social choice, in the approaches of Arrow and Sen). However, these details are not limited to the narrow sphere of personal life as it has been proposed by Buchanan (1996) and, consequently, can affect collective life.

\subsection{Free Will, Private Knowledge and Social Interaction}

When there is free will (and, consequently, uncertainty), common knowledge covers only the most general and superficial aspects. A consequence of the modern social division of labor and knowledge is that each individual has specific private knowledge of time and place (related to their specific conditions and options). One of the great contributions of Hayek (1988) was to show that there is no human being who can collect, process and make a discernment about the colossal collective knowledge, and thus showed the abysmal gap between what an individual can know and the knowledge of a collectivity.

In a world where individuals choose with free will to create new options or, simply, to make strategic use of surprise and secrecy, each of them generates changes and innovations that are not known or imagined by the rest of the community. The strategic secrets and the originality of the creation are part of strictly private and non-transferable knowledge.

In an interdependent social choice that is open to free will, there is mutual interdependence and, simultaneously, a mutual ignorance about the rules of the game and the possible consequences of the various strategic actions. This reality differs radically from the idealized scenario of game theory based on rational choice and pre-reconciled and predictable choices. This theory is deterministic because strategies and actions are subject to the calculation of probabilities. When a player has free will, by simple strategic use of the secrets, he will not behave according to the predicted and allegedly known strategies. Consequently, no exist a rational and clairvoyant actor who can know, foresee (and control) the choices and actions of his adversaries and allies.

Collective actions such as markets, migrations, democratic elections, and popular uprisings are subject to a constellation of social and natural variables. Perhaps a God with omnipotent power could know all the variables of the social and natural order, foresee their different combinations and the diversity of consequences of each combination and, then, discern and choose the best of all the desirable worlds. According to Shackle (1991), the theorists of rational choice 
and game theory have mistakenly assumed that individuals are a species of demi-gods with an extraordinary scope of information, knowledge, and choice.

From the perspective of the conventional social choice theory of Arrow (1963) and Sen (2018) it is assumed that individuals can choose, deliberately, complete and orderly social states in all their details. The criticism of Buchanan (1996) is correct because he shows an anti-liberal bias of Social Choice, since by choosing a complete social state each individual intends to impose their choices on the other individuals.

The deceptively libertarian (Nozick, 1974) raised a critique of Arrow and Sen's theory of social choice. This author defended the status quo (historically imposed social states) and reduced freedom to permissible individual actions. In the same wrong perspective is the contribution of Gaertner, Pattanaik, and Suzumura (1992) who reduce individual freedom to a set of permissible strategies and use the conventional game theory. In their view, it is assumed that individual players know the rules of the game and, also, can know the various combinations and consequences of the strategic actions of their rivals and allies that are related to their strategies.

General ideas about desired social states are fruit of free will. This ideal social statement can be imagined and outlined, in their more general aspects, by some great leaders who propose paths for revolutionary changes. Original individuals such as Jesus, Buddha, Marx, Bakunin, Tolstoy, and Gandhi have offered creative sketches of alternative social states.

The most loyal followers of creative geniuses such as those mentioned have implemented imperfect individual and collective choices and actions to materialize these utopias in real social states. The success of reformers and revolutionaries who have proposed processes of social transformation has been partial and, often, contradictory and counterproductive.

Mortal beings cannot anticipate or determine all the details of a social state, because this is part of a social process where each individual can put their dose of creativity (fruit of their free will). The alternative social states are not the result of a coherent construction of consensus, because the expectations of individuals are varied, dissimilar and generate persistent disagreements and conflicts. It is impossible to foresee the result of a social change because it would imply predicting the discoveries and inventions of scientists and technologists, forecast the stratagems and moves of military and economic leaders, and know in advance the most minimal libertarian choices of each and every one of the anonymous beings that intervene in the prolonged and uncertain processes of social change.

\section{Social Choice, Social Change and Class Conflict}

One of the most turbulent, contradictory and tragicomic interlude in the history of France began with an attempt at popular sovereignty (the French Revolution of 1789) that was then crushed by the anti-democratic coup d'état of Napoleon 
Bonaparte in 1799. During the 19th century, the unstable and contradictory evolution of social order continued. The hopes of popular sovereignty resurfaced with the insurgents of 1848 . However, after turbulent months of confrontations between rival and antagonistic social classes, the democratic process was again crushed by the coup d'état of Louis Bonaparte at the end of 1851 .

The aforementioned fragment in the history of democracy has a characteristic that is common with other realistic processes of social change, namely: collective choices do not culminate in the choice of a desired social state that positively reflects the preferences of all individuals. Individuals have different social conditions and quite different expectations and, consequently, they are grouped into social classes that are rival and even antagonistic. While in the conciliatory view and in the methodological individualism approach followed by theorists such as Arrow and Sen individual preferences can be added, in Marx's most realistic perspective, the elections are contradictory because individuals belong to rival and even antagonistic social classes. What exists is a permanent class struggle and each social class or inter-classist alliance or dictatorship seeks to impose its choices on the rest of society.

Diverse forms of democracy and dictatorship are unstable because social choices imposed by a social class (or a majority or minority alliance of social classes) are rejected and fought by the social sectors affected and by some rebels. However, there is a social order rooted in historical restrictions that significantly obstruct the possibilities of social change.

Marx understood that history (and we would say much of the existing social states) determines the choice of subjects and constrain their freedoms. Marx (1937: p. 5) explained that: "Men make their own history, but they do not make it as they please; they do not make it under self-selected circumstances, but under circumstances existing already, given and transmitted from the past. The tradition of all dead generations weighs like a nightmare on the brains of the living."

Although social restrictions generate some deterministic (historically predetermined) social choices, there is an opposite trend that lies in the truly libertarian individual elections. Genuine freedom, understood as free will, generates creative choices, not determined, surprising and, consequently, uncertain. However, freedom itself is restricted by the past and consequently, there is restricted free will and bounded uncertainty.

The uncertainty of free will is related to surprise, anarchistic, partially creative choices imposed on the rest of society by an individual or a collective. For example, the surprising coup d'état of Louis Bonaparte, emerges as a stormy imposition on the deceptive tranquility experienced by some social sectors. According to Marx (1937: p. 7): “... December 2 struck them like a thunderbolt from a clear sky ...".

The different interpretations and visions of the world are indications that there is no common language to the whole society. Consequently, the dissimilar 
subjective valuations of rival and antagonistic social classes and individuals prevail. According to Marx (1937: p. 3), the coup d'etat by Louis Bonaparte was interpreted differently by rival sectors of society, as Engels stressed: “... Immediately after the event that struck the whole political world like a thunderbolt from the blue, that was condemned by some with loud cries of moral indignation and accepted by others as salvation from the revolution and as punishment for its errors, but was only wondered at by all and understood by none ...”.

Finally, social change as an agonistic process of collective choices of different, dissimilar and even antipodal sectors or social classes is what occurs in a sequence of actions and reactions of classes that fight each other.

Marx (1937: pp. 58-59) described the sequential process of intense social class struggle that occurred in France during the brief period of less than three years (from February 24, 1848 to December 2, 1851). Between the opening (Universal-brotherhood swindle) until the end of the sequence (Victory of Bonaparte), the social choices were transitory. For a few weeks it dominated a class or a class alliance and later its rivals or enemies. The clashing classes were the pure bourgeoisie, the petty bourgeoisie, and the proletariat. In the end Dictator Bonaparte triumphed.

Although this episode may produce the sardonic laughter of those who believe in an inescapable dictatorship it is necessary to emphasize that the facts referred to here are a tiny fragment of history. Social change expresses an unfinished struggle between conservative social classes that defend given social states and more reformist or revolutionary social classes seeking important social changes.

\section{Empirical Evidence on Free Will and Historical Restrictions}

It is possible to verify that, at least at certain moments of their existence, some human beings have free will. Besides, there is no unavoidably established social order, immune to reformist and revolutionary attempts. However, free will is not unbound because an important part of the actions and behaviors of individuals, social classes and collectivities are determined by history.

Some available evidence shows that certain individuals can impose their will on the rest of society during a short time interval. Sometimes they can incorporate some changes in important aspects of the established social states. Libertarian choices originated in free will are sources of important reforms and revolutions.

\subsection{Libertarian Choices Due to the Strategic Secret}

Through strategic secrecy, some curious teenagers or the most daring libertine can enjoy a socially censored text as the classic of erotic literature, Lady Chatterley's lover. In a questionable example, Sen (2018: pp. 139-142) assumes that a libertine and a prudish have a complaint about the reading of the aforementioned text. Unlike Sen's controversial approach, in real life, individuals (whether polit- 
ical dissidents or adolescent rebels) often make strategic use of the secret to read what they please and, in some cases, to put it into practice without asking permission or social authorization.

There is an extensive set of individual actions (or small groups' actions) that are secret, surprising and considerably creative, and that are never subject to scrutiny by the great majority. The scientific discoveries, the artistic productions, and also the conspiracies and some insurrections are included in the set of fully creative acts that are a product of free will.

\subsection{Banksy Tries to Challenge the Market}

Recently the enigmatic street artist Banksy has subverted the rules of the game of a long-standing social choice such as that of auctions of artistic works and other positional relics, as can be seen in the article by Picford (2018). In the customary game of supply and demand, there is a happy ending (the equilibrium price). Nevertheless, the free will of the artist who programmed the destruction of a piece of his graphic work could have generated damage in the auction and, besides, altered some rules of the social game. Surely, contrary to the original wishes of the irreverent artist, the work was not completely destroyed. However, market strategists, also with creativity, responded with the counter-strategy of auctioning the altered work and at a higher price.

\subsection{Esler, a Lonely Hero against Nazism}

Nazism was a social choice, partly voluntary of the German people, during the period 1933-1945. This collective choice was the result of very harsh historical circumstances (the humiliating treaty of Versailles and the world economic crisis of the 1930s). Perhaps that was a fertile environment for the emergence of attractive proposals for desperate German people as the possible predominance of their race over the rest of the world. Although Hitler was obeyed with willing servility by millions of Germans, some individuals, through their free will, tried to change history.

In the film, 13 minutes directed by Hirschbiegel (2015) is narrated the tragic story of a lonely hero who fought against the absurd social order imposed by Hitler. It is possible to think that Georg Esler, presumably, in his imagination sketched a utopian social state without the existence of the evil Adolf Hitler and, consequently, worked in a solitary action to reach such a state. What we know is that Esler was, in itself, a ridiculous irrelevant variable (a poor worker who was condemned to make trivial actions, without pain or glory). However, Esler (using his free will and with full use of strategic secrecy) put a bomb to kill Hitler. Sadly for another series of seemingly "irrelevant" factors (the rudimentary technology and the Führer's whims), the lone hero failed for only 13 minutes. The unsuccessful bet of the hapless Esler meant his ruin and, also, the painful postponement of the victory against the Nazis. However, if he had managed to end Hitler's life then, through the change of a relevant detail, he would have made a 
huge change in history.

\subsection{The Bittersweet Einstein's Libertarian Triumph}

At the beginning of the 20th century, the brilliant Einstein formulated (without knowing) a theoretical basis for building the atomic bomb; towards 1939, with his colleague Leó Szilárd, they wrote a decisive letter to the American President Roosevelt to tell him that the Nazis had achieved nuclear fission with Uranium and to suggest that the allies should advance in the construction of the bomb (Atomic-Archive, 2015). Like many pacifists, Einstein yearned for a world without the Nazis and, with his free will, worked to achieve such a social state but, obviously, he did not anticipate or desire Hiroshima and Nagasaki and, perhaps, did not predict the hellish uncertainty with the expansion of atomic power.

The creators of the atomic bomb and those who detonated it more than 70 years ago have transferred enormous risks to humanity, to such an extent that the strategist of the cold war, the academic (Schelling, 2005), affirmed that every day we live thanks to a miracle.

An extensive set of scientific discoveries is impregnated by the free will of one's realities and the observed variables that seem to play whimsically with the ordered searches of adventurers and scientists. The writer Taleb (2008) finds that the adventurous seekers, like Columbus, were investigating something known (for example, a new route to reach the Indies) and, surprisingly, find something not searched (the American continent).

For the world of social transformations, the promoters of a revolutionary change can seek a paradise (for example, some communism) and end up generating a hell (the Stalinist dictatorship). It also happens that some heroes, like Einstein, we're looking for a pressing solution (a world without Hitler and the Nazis) and ended up leaving a world more insecure due to the development of the atomic bomb.

Jesus, with his dozen apostles, and with messages like the Sermon on the Mount, promoted a beautiful social state, which centuries later has been degenerated by the Catholic Church and by corrupt ecclesiastical leaders with horrors such as the Inquisition and the Crusades. Marx, Engels and their followers devised a utopian social state (communism), suggested that a dictatorship of the proletariat would be the most appropriate means, and did not foresee dictatorial monsters such as Stalin and Mao.

In a world where any individual can have free will for the good and the bad, it often happens that the contribution of any person to collective history is altered and even seriously deformed.

\section{Conclusion}

The theoretical remark is raised to this point and the brief discussion about some historical facts leads to two specific conclusions:

First: the existence of class struggle and free will involves situations of perma- 
nent conflict, disequilibrium, dissent, and instability. The happy endings of consensus and coherent social ordering that have craved authors like Arrow and Sen are more compatible with determinism and with the absence of freedom.

Second: the various particles and creatures of nature are also players with free will that often alter and spoil the various creations of pedantic human beings. As can be seen in the legendary art of war (Tzu, 2007), ancient wisdom was more complete than the reductionist game theory: they knew that with human beings they also played the terrain and the climate. In future investigations, it would be imperative to think about the problems of social choice in a world where the diverse beings of nature have free will. This would imply an interdisciplinary dialogue to understand advances in philosophy and natural sciences such as those presented by Heisenberg (2007) and Conway \& Kochen (2009).

At the time of working on the latest reviews and updates for this article, a huge social transformation is beginning to occur, perhaps worldwide. This may be one of the most colossal processes of social and economic change in history. For the time being, this process does not result from the actions of the free will of a revolutionary social class or of some tremendously creative leaders. What has happened has been generated by an act of nature's free will. The surprising invasion and rapid spread of the SARS-CoV-2 virus on a planetary scale have created chaos in the social order. The invasion of this new virus in the human body may be a consequence of the errors and ecological damage caused by the current social order. The spread of this virus across several continents in just a few weeks is also a result of the inertia caused by historical restrictions. Businessmen, rulers, tourists and citizens in general wanted to follow a normal life before a new and surprising event. Now the reactions are late and huge bankruptcies in the economic and social spheres will be noticed. Individuals and societies are reacting with previously unimaginable reactions. Because of the crisis there is a global clamor for creative responses. The challenge will be, once again, to overcome ancient historical restrictions. This virulent storm may be the threshold for a kind of rebirth of free will on the part of dissatisfied social classes and highly creative and revolutionary individuals.

\section{Acknowledgements}

This article is one of the results of my theoretical research during the sabbatical year, kindly granted by the Universidad del Rosario.

\section{Conflicts of Interest}

The author declares no conflicts of interest regarding the publication of this paper.

\section{References}

Arrow, J. K. (1963). Social Choice and Individual Values. New York: Wiley.

Atomic-Archive (2015). Atomicarchive. http://www.atomicarchive.com http://www.atomicarchive.com/Docs/Begin/Einstein.shtml 
Barrow, J. (1998). The Limits of Science and the Science of Limits. Oxford: Oxford University Press.

Betacinema (2015). Betacinema. https://www.betacinema.com https://www.betacinema.com/13minutes

Buchanan, J. (1996). An Amgiguity in Sen's Allegued Proof of the Impossibility of a Pareto Libertarian. Analyse \& Kritik, 18, 118-125. https://doi.org/10.1515/auk-1996-0108

Conway, J., \& Kochen, S. (2009). The Strong Free Will Theorem. Notices of the AMS, 56, 226-232.

Ekstrom, L. (2011). The Free Will Is Not a Mystery. In R. Kane (Ed.), The Oxford Handbook of Free Will (pp. 266-281). Oxford: Oxford University Press. https://doi.org/10.1093/oxfordhb/9780195399691.003.0018

Frankfurt, H. (1971). Freedom of the Will and the Concept of a Person. Journal of Philosophy, 68, 5-20. https://doi.org/10.2307/2024717

Gaertner, W., Pattanaik, P., \& Suzumura, K. (1992). Individual Rights Revisited. Economica, 59, 161-177. https://doi.org/10.2307/2554744

Hayek, F. (1960). The Constitution of Liberty. London: Routledge.

Hayek, F. (1988). The Fatal Conceit: The Errors of Socialism. London: Routledge. https://doi.org/10.7208/chicago/9780226321158.001.0001

Heisenberg, W. (2007). Physics and Philosophy: The Revolution in Modern Science. New York: Harper Perennial Classics.

Hirschbiegel, O. (2015). 13 Minutes [Film].

Hirschman, A. (1982). Shifting Involvements: Private Interest and Public Action. Princeton, NJ: Princeton University Press.

Kane, R. (2011). Introduction: The Contours of the Conteporarly Free-Will Debates. En The Oxford Handbook of Free Will (pp. 3-39). Oxford: Oxford University Press. https://doi.org/10.1093/oxfordhb/9780195399691.003.0001

Knight, F. (1982). Freedom and Reform: Essays in Economics and Social Philosophy. Indianapolis, IN: Liberty Fund.

Marx, K. (1937). The Eighteenth Brumaire of Louis Bonaparte. Moscow: Progress Publishers .

Nozick, R. (1974). Anarchy, State and Utopia. New York: Basic Books.

Picford, J. (2018). Banksy Painting 'Self-Destructs' on Podium in Auction Prank (p. 2). Financial Times.

Popper, K. (2001). All Life Is Problem Solving. London: Routledge.

Portes, A. (2006). Institutions and Development: A Conceptual Reanalysis. Population and Development Review, 32, 232-266. https://doi.org/10.1111/j.1728-4457.2006.00117.x

Schelling, T. (2005). Nobel Prize. https://www.nobelprize.org/prizes/economic-sciences/2005/schelling/lecture/

Sen, A. (1967). Isolation, Assurance and the Social Rate of Discount. Quarterly Journal of Economics, 81, 112-124. https://doi.org/10.2307/1879675

Sen, A. (2009). The Idea of Justice. Cambridge, MA: Harvard University Press. https://doi.org/10.2307/j.ctvjnrv7n

Sen, A. (2018). Collective Choice and Social Welfare: An Expanded Edition. Boston, MA: Harvard University Press. https://doi.org/10.4159/9780674974616 
Shackle, G. L. (1966). The Nature of Economic Thought: Selected Papers 1955-1964. Cambridge: Cambridge University Press.

Shackle, G. L. (1990). Time, Expectations, and Uncertainty in Economics. Hampshire: Billing \& Sons.

Shackle, G. L. (1991). Epistemics and Economics: A Critique of Economic Doctrines. London: Routledge.

Skinner, Q. (1998). Liberty before Liberalism. Cambridge: Cambridge University Press. https://doi.org/10.1017/CBO9781139171274

Taleb, N. (2008). The Black Swan: The Impact of the Highly Improbable. New York: Penguin.

Taleb, N. (2018). Skin in the Game: Hidden Asymmetries in Daily Life. New York: Random House.

Tzu, S. (2007). The Art of War. Boston, MA: Filiquarian Publishing. 